\title{
Jurist-Diction
}

Volume 4 No. 6 November 202

\section{Indikasi Praktek Monopoli Dalam Pembayaran Tiket Kereta Api (KAI Access) Melalui Dompet Elektronik di Indonesia}

\author{
Enudio Aprilian Utoyo \\ enudio.aprilian.utoyo-2017@fh.unair.ac.id \\ Universitas Airlangga
}

\begin{abstract}
How to cite:
Enudio Aprilian Utoyo'Indikasi Praktek Monopoli Dalam Pembayaran Tiket Kereta Api (KAI Access) Melalui Dompet Elektronik di Indonesia' (2021) Vol. 4 No. 6 Jurist-Diction.

Histori artikel:

Submit 13 Agustus 2021; Diterima 15 Oktober 2021;

Diterbitkan 5 November 2021.

DOI:

10.20473/jd.v4i6.31848

p-ISSN: 2721-8392

e-ISSN: 2655-8297
\end{abstract}

\section{Abstract}

This article, which aims to analyze the indications of unfair business competition by PT. Kereta Api Indonesia in selling local train tickets through the KAI Access application with payment methods via electronic wallets regulated under Law Number 5 of 1999 concerning the Prohibition of Monopolistic Practices and Unfair Business Competition and also aims to determine whether the occurrence of deadweight loss is caused by on the existence of a monopoly in a market. This writing uses a normative research method, namely by researching the applicable laws and regulations by using a statutory approach, conceptual approach, and case study. Monopoly is a condition where there is only one business actor in a market, this condition becomes a problem if the business actor uses his monopoly power to dominate the market so that there are barriers to entry into the market. In this case, the purchase of local train tickets through KAI Access can only be paid for using the LinkAja electronic wallet.

Keywords: Monopoly; Deadweight Loss; Elecronic Wallet.

\begin{abstract}
Abstrak
Dalam artikel ini yang bertujuan untuk menganalisis dari adanya indikasi persaingan usaha yang tidak sehat oleh PT. Kereta Api Indonesia dalam penjualan tiket kereta api lokal melalui aplikasi KAI Access dengan metode pembayaran melalui dompet elektronik yang diatur berdasarkan oleh Undang-Undang Nomor 5 Tahun 1999 tentang Larangan Praktek Monopoli dan Persaingan Usaha Tidak Sehat dan juga bertujuan untuk mengetahui apakah terjadinya deadweight loss di sebabkan atas adanya monopoli dalam suatu pasar. Penulisan ini menggunakan metode penelitian normatif yaitu dengan cara meniliti terhadap peraturan perudang-undangan yang berlaku dengan menggunakan pendekatan perundang-undangan, pendekatn konseptual dan case study. Monopoli merupakan kondisi dimana hanya ada satu pelaku usaha dalam suatu pasar, kondisi tersebut menjadi masalah apabila pelaku usaha menggunakan kekuatan monopoli nya untuk menguasai pasar sehingga adanya hambatan masuk ke dalam pasar tersebut. Dalam hal ini terdapat pembelian tiket kereta api lokal melalui KAI Access hanya dapat di bayar menggunakan dompet elektronik LinkAja.

Kata Kunci: Monopoli; Deadweight Loss; Dompet Elektronik.
\end{abstract}

Copyright (c) 2021 Enudio Aprilian Utoyo 


\section{Pendahuluan}

Sebagai konsekuensi adanya perkembangan zaman menuju era revolusi industri 4.0 hal ini berdampak juga pada sistem pembayaran dengan berkembangnya metode pembayaran secara digital. Industri 4.0 sendiri merupakan sebuah perubahan secara menyeluruh dengan cara adanya penggabungan aspek digital dan konvensional. ${ }^{1} \mathrm{Di}$ Indonesia hal tersebut ditandai dengan maraknya penggunaan uang elektronik yang berbasis Chip dan dompet digital yang berbasis Server. Sejauh ini, setidaknya sudah ada 51 penyelenggara uang elektronik server based dan chip based yang telah terdaftar dan memiliki izin resmi dari Bank Indonesia. ${ }^{2}$

Dalam penggunaannya dapat dikategorikan sebagai uang elektronik adalah apabila diterbitkan berdasarkan besaran uang yang disetor kepada penerbit (penyedia jasa uang elektronik), kemudian uang tersebut disimpan secara elektronik baik melalui media server atau chip. ${ }^{3}$ Perbedaan server based dan chip based ada pada bentuk fisiknya, dalam chip based konsumen dapat menggunakan uang elektronik tersebut dengan memiliki kartu secara fisik seperti penggunaan e-money pembayaran pada tol sedangkan yang berbasis server tidak terdapat kartu fisik sehingga konsumen hanya memiliki aplikasi yang digunakan untuk melaksanakan pembayaran seperti membayar melalui gopay. Dalam hal ini Linkaja dapa dikategorikan sebagai uang elektronik yang berbasis server atau umum disebut sebagai dompet elektronik karena penggunaannya tidak dengan adanya kartu fisik melainkan hanya secara server melalui aplikasi. Lebih lanjut, Di Indonesia regulasi mengenai dompet elektronik diatur dalam Peraturan Bank Indonesia Nomor 18/40/PBI/2016 Tentang Penyelenggaraan Pemrosesan Transaksi Pembayaran, dijelaskan bahwa dompet elektronik merupakan sebuah

\footnotetext{
${ }^{1}$ Jefry Tarantang et al, 'Perkembangan Sistem Pembayaran Pada Era Revolusi Industri 4.0 Di Indonesia'(2019) 4 Jurnal Al-Qaradh.[64].

${ }^{2}$ Bank Indonesia, 'Daftar Penyelenggara Uang Elektronik yang Telah Memperoleh Izin dari Bank Indonesia Per 27 Mei 2020’ (Bank Indonesia 2020) https://www.bi.go.id/id/sistem-pembayaran/informasi-perizinan/uang-elektronik/penyelenggara-berizin/Contents/Default.aspx accessed pada 12 September 2020.

${ }^{3}$ Pasal 1 Angka 3 Peraturan Bank Indonesia Nomor 20/6/PBI/2018 Tentang Uang Elektronik.
} 
layanan secara elektronik untuk melaksanakan pembayaran ataupun untuk menampung dana. ${ }^{4}$

Melihat tingginya angka pengguna dari dompet digital tersebut hal ini membuat PT. Kereta Api Indonesia (PT. KAI) sebagai salah satu perusahaan BUMN dan memiliki jumlah pengguna jasa yang besar untuk melakukan kerja sama dengan salah satu dari penyedia jasa dompet digital tersebut. PT. KAI akhirnya meluncurkan inovasi terbarunya tersebut dengan bekerja sama dengan Linkaja yang ternyata merupakan juga merupakan perusahaan Financial Technology milik negara atau BUMN. Seperti yang dikatakan PT. KAI dalam siaran persnya bahwa seluruh pembelian tiket kereta api baik kereta api jarak jauh dan kereta api lokal hanya dapat dipesan melalui aplikasi KAI Access yang merupakan aplikasi milik PT. KAI untuk melakukan pembelian tiket kereta api, pembatalan tiket kereta api, dan pengubahan jadwal tiket kereta api. ${ }^{5}$

Dalam aplikasi KAI Access terdapat dua jenis perjalanan kereta api yang ditawarkan yaitu kerta api jarak jauh dan kereta api lokal. Pada kereta api jarak jauh seperti hanya menjual tiket perjalanan kereta api yang tergolong ke dalam perjalanan yang jauh seperti perjalanan Jakarta-Surabaya. Pada kereta api lokal hanya menjual tiket perjalanan kereta api yang tergolong perjalanan yang dekat kurang lebih dengan jarak di bawah 80 kilometer.

Oleh karena adanya keadaan dimana hanya ada satu penyedia jasa pembayaran tiket kereta api lokal khususnya melalui media dompet digital maka hal tersebut dikhawatirkan akan adanya praktik monopoli yang mana akan terjadinya suatu persaingan usaha yang tidak sehat. KPPU sebagai lembaga yang memiliki wewenang untuk mengawasi jalannya kegiatan usaha atau bisnis di dalam yurisdiksi Indonesia terkait adanya praktik monopoli ataupun persaingan usaha yang tidak sehat sebagai mana diatur dalam UU No. 5 Tahun 1999 Tentang Larangan Praktek Monopoli dan

\footnotetext{
${ }^{4}$ Pasal 1 Angka 7 Peraturan Bank Indonesia Nomor 18/40/PBI/2016 Tentang Penyelenggaraan Pemrosesan Transaksi Pembayaran.

${ }^{5}$ Public Relations KAI, (KAI 2020) "Seluruh KA Lokal Bisa Dibeli MElalui KAI Access", https://kai.id/information/full_news/2269-seluruh-ka-lokal-bisa-dibeli-melalui-kai-access, accessed pada 13 September 2020.
} 
Persaingan Usaha Tidak Sehat telah memberikan peringatan kepada PT. KAI terkait adanya dugaan praktik monopoli tersebut. ${ }^{6}$ Hal tersebut akan mengarah menjadi suatu bentuk diskriminatif bagi penyedia jasa dompet digital lainnya dengan adanya hanya ada satu penyedia jasa pembayaran dompet elektronik yaitu Linkaja. $^{7}$

Pelaku usaha yang ada di dalam pasar monopoli ini dapat memaksimalkan keuntungannya dalam berbisnis karena merupakan perusahaan yang tunggal dalam pasar tersebut, artinya pelaku usaha tersebut memiliki kuasa atau power untuk mengontrol pasar tersebut. Kekuatan tersebut memliki dampak kepada konsumen pada pasar tersebut yaitu terkait deadweight loss. Konsumen pada pasar monopoli tersebut akan merasakan penurunan surplus konsumen dan surplus produsen sehingga konsumen tidak dapat menghindari penetapan harga yang tinggi dan produksi barang yang rendah oleh dari produsen. Alhasil konsumen mendapatkan mengalami penurunan kesejahteraan atas adanya monopoly power oleh produsen. ${ }^{8}$

Monopoli sebagai sebuah perbuatan yang tergolong ke dalam suatu Kegiatan Yang Dlarang berdasarkan UU No. 5 Tahun 1999 Tentang Larangan Praktek Monopoli dan Persaingan Usaha Tidak Sehat pada dasarnya merupakan hal yang diperbolehkan namun, yang tidak diperbolehkan adalah praktik monopoli hal ini di inisiasi karena sebuah keadaan hanya ada satu pelaku usaha tidak relevan lagi maka dari itu yang ditekankan adalah perilaku dari monopoli tersebut. ${ }^{9}$ Dengan adanya dugaan praktik monopoli tidak hanya pelaku usaha pesaing saja yang akan mendapat kerugian namun, masyarakat pun akan merasakan hal yang sama karena tidak memiliki pilihan yang lain.

\footnotetext{
${ }^{6}$ Pasal 30, Undang-Undang Nomor 5 Tahun 1999 Tentang Larangan Praktek Monopoli dan Persaingan Usaha Tidak Sehat.

${ }^{7}$ Siaran Pers KPPU Nomor 28/KPPU-PR/V/2020, (KPPU 2020) “ KPPU Minta PT. KAI Serius Dalam Menciptakan Persaingan Dalam Kerja Sama Bisnisnya”, https:/www.kppu.go.id/id/ wp-content/uploads/2020/05/Siaran-Pers-No.-28_KPPU-PR_V_2020.pdf, accessed pada 16 September 2020.

${ }^{8}$ Gigih Pratomo, “Analisis Welfare Loss Konsumen Sambungan Langsung Jarak Jauh Telepon Tetap Di Indonesia”, (2010) 8 Equilibrium.[189-190].

9 Komisi Pengawas Persaingan Usaha, Pedoman Pelaksanaan Pasal 17 (Monopoli) Undang-Undang Nomor 5 Tahun 1999 Tentang Larangan Praktek Monopoli dan Persaingan Usaha Tidak Sehat.
} 


\section{Metode Penelitian}

Tipe penelitian yang digunakan dalam penulisan ini menggunakan tipe penelitian normatif. Tipe penelitian normatif atau doctrinal research dengan cara meneliti terhadap peraturan perundang-undangan yang berlaku, pandangan sarjana hukum, literatur hukum, dan membandingkan hukum yang terkait dengan permasalahan pada penulisan ini. ${ }^{10}$ Pendekatan yang digunakan dalam penelitian ini adalah pendekatan perundang-undangan (statute approach), pendekatan konseptual (conceptual approach), dan Case study.

Pendekatan perundang-undangan atau statute approach merupakan pendekatan yang dilakukan dengan cara menganalisis peraturan perundangundangan yang berupa legislasi dan regulasi. Dengan menggunakan pendekatan peraturan perundang-undangan peneliti mengkaji antar peraturan perundangundangan yang berlaku ${ }^{11}$ hal tersebut dilakukan sebagail dasar permulaan untuk melakukan analisis karena peraturan perundang-undangan menjadi titik fokus dalam penelitian secara normatif. Pendekatan konseptual atau conceptual approach digunakan dalam suatu penelitian dengan merujuk ke dalam konsep hukum, asas hukum, hingga pandangan sarjana atau doktrin hukum ${ }^{12}$ dengan menggunakan pendekatan konseptual dapat ditemukan pemikiran-pemikiran yang berkaitan dengan isu yang akan dikaji. Pendekatan case study merupakan sebuah pendekatan yang dilakukan dengan merujuk kepada kasus-kasus lain yang serupa namun belum memiliki kekuatan hukum yang tetap. ${ }^{13}$

\section{Bentuk Struktur Pasar Monopoli}

Ciri-ciri pasar monopoli adalah sebagai berikut:

i. Industri Satu Perusahaan

Hanya terdapat satu pelaku usaha atau suatu kelompok pelaku usaha yang menguasai produksi dan atau pemasaran atas suatu produk tertentu karena memang tidak ada penjual lain yang menjual barang atau jasa tersebut.

\footnotetext{
${ }^{10}$ Peter Mahmud Marzuki, Penelitian Hukum (2001) 16 Yuridika.[104].

${ }^{11}$ Peter Mahmud Marzuki, Penelitian Hukum (Kencana Prenada Media Group 2011).[35].

${ }^{12}$ ibid.[177-178].

${ }^{13}$ ibid.[159].
} 
ii. Tidak Ada Barang Substitusi

Pembeli tidak memiliki pilihan lain untuk membeli barang atau jasa tersebut. ${ }^{14}$ Sebagai contoh adalah air, dalam penggunaannya air sangatlah fundamental untuk kehidupan sehari-hari belum ditemukan adanya barang pengganti dari air untuk mandi, menyiram ataupun kebutuhan lainnya.

iii. Adanya Hambatan untuk Masuk ke Dalam Pasar (Barrier to Entry)

Hal yang paling mendasar dalam pasar monopoli adalah adanya hambatan bagi para penjual untuk masuk ke dalam suatu pasar. Hal ini menjadi ciri yang paling utama dalam pasar monopoli karena memang dengan adanya satu penjual dan tidak terdapatnya barang pengganti mengakibatkan sangat mustahil bagi para penjual lainnya untuk masuk ke dalam pasar tersebut.

iv. Menguasai Penentuan Harga (Price Setter)

Setiap penjual yang ada pada pasar monopoli dapat dengan leluasa menentukan harga atas barang atau jasa yang diperdagangkan tanpa memperhatikan keterkaitannya dengan para pembeli. Karena setiap penjual dalam pasar monopoli merea sadar bahwa hanya merekalah yang memiliki kemampuan untuk menjual barang atau jasa tersebut tanpa ada pesaing dan tidak ada barang penggantinya, sehingga para pembeli secara mau tidak mau pasti akan membeli darinya.

v. Promosi Tidak Diperlukan

Sebagai satu-satunya penjual yang ada pada pasar tersebut setiap penjual yang ada dalam pasar monopoli tidak perlu melakukan kegiatan promosi untuk menarik para calon pembeli untuk membeli barang atau jasanya. Karena dengan sendirinya para pembeli pasti akan memilih dan membeli barang dan jasa tersebut karena para pembeli tidak memiliki pilihan lain atas barang atau jasa yang mereka inginkan. Sehingga penjual pada pasar monopoli pasti tetap akan memiliki konsumen tetapnya. ${ }^{15}$

\section{Pasar Bersangkutan}

Berkaca pada pasal 1 angka 10 Undang-undang Nomor 5 Tahun 1999 tentang Larangan Praktek Monopoli dan Persaingan Usaha Tidak Sehat bahwa pasar bersangkutan di definisikan sebagai berikut: "Pasar bersangkutan adalah pasar yang berkaitan dengan jangkauan atau daerah pemasaran tertentu oleh pelaku usaha atas barang dan jasa yang sama atau sejenis atau substitusi dari barang dan atau jasa tersebut". ${ }^{16}$

Berdasarkan defnisi tersebut dapat ditarik garis lebih lanjut bahwa di dalam pasar bersangkutan terdiri atas dua komponen yaitu, pasar bersangkutan produk

\footnotetext{
${ }^{14}$ Andi Fahmi Lubis, [et al], Hukum Persaingan Usaha (Komisi Pengawas Persaingan Usaha 2017).[48].

${ }^{15}$ ibid. [48-49].

${ }^{16}$ Pasal 1 Angka 10 Undang-Undang Nomor 5 Tahun 1999 Tentang Larangan Praktek Monopoli dan Persaingan Usaha Tidak Sehat.
} 
(relevan product market) dan pasar bersangkutan geografis (relevant geographic market). ${ }^{17}$

\section{Pasar Bersangkutan Produk (Relevant Product Market)}

Pasar bersangkutan produk dapat diartikan sebagai sebaran dari produk dari para pelaku usaha, artinya semua produk para pesaing dan termasuk juga dengan produk yang dapat dijadikan sebagai substitusi. ${ }^{18}$ Dalam pasar bersangkutan produk terdapat adanya indikator sebagai pertimbangan untuk melihat ke dalam suatu pasar bersangkutan produk yaitu, indikator harga dan karakter dan kegunaan produk. Di dalam indikator harga akan suatu harga atas suatu barang akan menandakan apakah kompetitif atau tidak kompetitif, jika tidak kompetitif maka biasanya akan ditandai dengan pasar bersangkutan tersebut terlalu luas. ${ }^{19}$

Sedangkan dalam faktor karakter dan kegunaan produk setidaknya ada barang pengganti yang mirip (close substitute) tanpa harus adanya barang pengganti yang benar-benar sama (perfect substitue). Maka dari itu yang paling terpenting adalah pemanfaatannya, konsumen dapat memilih suatu barang dengan bermcam tipe merk yang ada dan tidak peduli kualitasnya seperti apa selama masih memiliki kegunaan yang sama. ${ }^{20}$ Untuk membuktikan apakahh LinkAja berada dalam pasar bersangkutan produk yang sama dengan dompet elektronik yang lainnya seperti OVO, Gopay, ShopeePay, Dana harus melihat ketiga poin diatas yaitu karakteristik barang, fungsi, dan harga.

Berdasarkan fungsi barangnya secara umum jika LinkAja disandingkan dengan dompet elektronik yang lainnya masyarakat menggunakannya sebagai untuk menyimpan uang sebagaimana namanya 'dompet' dan digunakan juga sebagai alat pembayaran. ${ }^{21}$ Kemudian dari segi karakteristiknya jika dilihat secara

\footnotetext{
${ }^{17}$ R. Shyam Khemani, John Clark, A Framework For The Design And Implementation of Competition Law and Policy (The World Bank 1999).[10].

${ }^{18}$ Peraturan KPPU No. 3 Tahun 2009 Tentang Pedoman Penerapan Pasal 1 Angka 10 Tentang Pasar Bersangkutan Berdasarkan Undang-Undang Nomor 5 Tahun 1999 Tentang Larangan Praktek Monopoli dan Persaingan Usaha Tidak Sehat.

${ }^{19}$ ibid.

${ }^{20}$ ibid.

${ }^{21}$ Muhammad Fahryan Putra, Lucky Daffa Nugroho, 'Perlindungan Hukum Pengguna Diompet Elektronik Atas Hilangnya Uang Elektronik’ (2020) 1 Law Prohuter.[482].
} 
fisik atau bentuknya LinkAja dengan OVO, Gopay, ShopeePay, Dana sama-sama menggunakan aplikasi untuk menggunakan dompet elektronik tersebut tanpa harus adanya memiliki kartu secara fisik (serever based) artinya semuanya terintegrasi secara internet. Lebih lanjut dari sisi harga LinkAja dengan OVO, Gopay, ShopeePay, Dana tidak ada perbedaan harga yang signifikan karena semuanya dapat di miliki secara gratis dengan hanya mengunduh aplikasinya dan mendaftar sebagai pengguna, yang membedakan dri segi harga hanyalah promo-promo yang ditawarkan oleh masing penyedia jasa dompet elektronik. Poin harga disini menjadi sangatlah penting karena masyarakat dalam penggunaanya sangat bergantung kepada harga dari produk yang dijual sehingaa dapat berdampak langsung terhadap pilihan barang penggantinya.

Setelah melihat dari segi karakteristik, fungsi, dan harga dari suatu produk terdapat satu unsur lagi yang dapat dilihat apakah produk tersebut berada pada pasar yang sama yaitu interchangeable apakah barang satu dengan yang lainnya merupakan tergantikan. Artinya apabila dari salah satu produk tersebut tidak ada di pasar atau hilang apakah konsumen mau beralih kepada produk yang lainnya. Berdasarkan survey dilakukan oleh NeuroSensum yang dilakukan kepada 1.000 responden yang dilakukan pada November 2020 sampai dengan Januari 2021 bahwa masyarakat mau menggunakan dompet elektronik lainnya tanpa hanya tertuju kepada satu produk saja, bahkan banyak yang memiliki lebih dari satu dompet elektronik di setiap orang. ${ }^{22}$ Berdasarkan penilaian dari aspek karakteristik, fungsi, harga, dan fleksibilitas barang bagi konsumen tersebut LinkAja dapat dikatakan berada pasar bersangkutan produk yang sama dengan dompet elektronik lainnya seperti OVO, Gopay, ShopeePay, Dana.

\section{Pasar Bersangkutan Geografis (Geographic Relevant Market)}

Pasar bersangkutan geografis secara sederhana dapat dikatakan sebagai sebuah cakupan dari suatu pasar berdasarkan geografis atau wilayah tersebut. Ada beberapa

\footnotetext{
${ }^{22}$ Fahmi Ahmad Burhan, "Riset Awal 2021: Dompet Digital ShopeePay Kalahkan Gopay dan OVO” (Katadata 2021), https://katadata.co.id/pingitaria/digital/603e0bea85b36/riset-awal2021-dompet-digital-shopeepay-kalahkan-gopay-dan-ovo, accessed pada 8 Agustus 2021.
} 
faktor yang dapat mempengaruhi cakupan wilayah atas produk tersebut. Namun, sebagai konsekuensi dari adanya perkembangan zaman yang merubah segalanya menjadi berbasis daring (online) maka mengakibatkan cakupan dari pasar geografis tersebut menjadi sangat luas dan dapat dikatakan tanpa adanya hambatan. ${ }^{23}$ Sebagai gambaran apabila ada pembeli yang membeli roti pada kota A dan kemudian dia berhenti membeli roti tersebut dan mulai membeli roti pada kota $\mathrm{B}$, maka kedua penjual tersebut berada dalam pasar geografis yang sama. ${ }^{24}$

\section{Analisis Indikasi Tindakan Anti Persaingan yang Dilakukan oleh PT.KAI}

Pada bulan September 2019 PT. KAI melakukan peningkatan pelayanan dengan bekerjasama dengan LinkAja terkait pembayaran tiket kereta api. LinkAja merupakan penyedia jasa layanan keuangan digital yang merupakan gabungan dari beberapa beberapa Badan Usaha Milik Negara yaitu, Telkomsel, Bank Mandiri, Bank Indonesia, Bank Rakyat Indonesia, Bank Tabungan Negara, Pertamina, dan Asuransi Jiwasraya. Jadi melalui aplikasi KAI Access dalam hal pemesanan tiket Kereta Api lokal terkait pembayarannya khususnya menggunakan dompet elektronik yang hanya dapat dilakukan melalui LinkAja.

Kereta api lokal tidaklah sama dengan kereta api antar kota atau jarak jauh. Pada Kereta api lokal titik perbadaannya terdapat pada jarak yang ditempuh pada perjalanan tersebut, umumnya jarak tersebut hanya berkisar sekitar sejau 50 kilometer dengan maksimal jarak sejauh 100 kilometer. Artinya, pada kereta api lokal hanya menyediakan jasa untuk perjalanan dengan jarak yang dekat saja kemudian, pada kereta api lokal tersebut akan berhenti pada setiap stasiun yang dilewati. Jika dilihat secara kasat mata maka jasa yang disediakan oleh kereta api lokal akan terlihat mirip dengan kereta komuter namun, pada kereta komuter intensitas keretanya lebih tinggi dibandingkan dengan kereta api lokal maka dari itu pada kereta komuter frekuensi keretanya lebih sering jika dibandingkan dengan kereta api lokal.

\footnotetext{
${ }^{23}$ ibid.

${ }^{24}$ John H. Shenefield, Irwin M. Stelzer, The Antitrust Laws: A primer (The AEI Press 2001).[31].
} 
Berdasarkan Siaran Pers KPPU Nomor 28/KPPU-PR/V/2020 tentang “KPPU Minta PT. KAI Serius Dalam Menciptakan Persangan Dalam Kerja Sama Bisnisnya" bahwa ternyata dengan adanya kerjasama diantara PT. KAI dengan LinkAja dalam hal pembayaran tiket kereta api lokal dengan menggunakan dompet elektronik LinkAja disinyalir bahwa akan menimbulkan persaingan usaha yang tidak sehat. Karena nyatanya per tanggal 1 September 2019 PT. KAI mengeluarkan kebijakan bahwa segala bentuk pemesanan tiket Kereta Api Lokal hanya dapat di pesan dengan mengakses pada aplikasi KAI Access secara daring dan hanya dapat dilakukan pembayaran menggunakan dompet elektronik LinkAja. ${ }^{25}$

Di dalam siaran pers tersebut dijelaskan bahwa Dengan terjalinnya kerjasama tersebut maka mengakibatkan hanya ada satu bentuk cara pembayaran yaitu menggunakan dompet elektronik yang dimiliki oleh LinkAja maka dari itu KPPU sebagai garda terdepan dalam hal pengawasan dan penanganan terkait persaingan usaha mengindikasikan bahwa dikhawatirkan kegiatan tersebut akan memicu adanya praktik monopoli dan persaingan usaha tidak sehat hal tersebut timbul atas inisiatif dari pihak KPPU sendiri.

Jika dilihat berdasarkan pangsa pasarnya berdasarkan survey yang dilakukan oleh Snapcart selama kuartal I tahun 2021 dihasilkan data bahwa pangsa pasar penggunaan dompet elektronik din indonesia adalah sebagai berikut yang di pimpin oleh ShopeePay pada posisi pertama dengan sebanyak 38\% dari total porsi pangsa pasar kemudian diikuti secara urut oleh Ovo (19\%), Gopay (19\%), Dana (17\%), dan LinkAja (7\%). ${ }^{26}$ Dapat dikatakan bahwa kelima produk dompet elektronik tersebut berada pada pasar yang sama dan merupakan pesaingnya satu dengan yang lainnya. Sehingga sudah selayaknya dapat memiliki kesempatan bersaing secara sehat dan adil dalam hal metode pembayaran tiket kereta api lokal melalui KAI Access.

\footnotetext{
${ }^{25}$ Siaran Pers KPPU Nomor 28/KPPU-PR/V/2020.

${ }^{26}$ Antara, "Lima Dompet Digital Paling Banyak DIgunakan Selama Kuartal I", (Media Indonesia 2021) https://mediaindonesia.com/ekonomi/394085/lima-dompet-digital-paling-banyakdigunakan-selama-kuartal-i, accessed pada 8 Agustus 2021.
} 
Hal ini juga serupa dengan apa yang terjadi pada kasus lainnya yaitu terkait adanya indikasi praktik monopoli yang dilakukan oleh OVO dalam kasus antara OVO dengan PT. Sky Parking Utama. OVO merupakan penyedia jasa pembayaran yang berbasis tunai sama seperti LikAja. PT. Sky Parking merupakan sebagai pelaku usaha yang menyediakan jasa pengelolaan lahan parkir. Yang menjadi permasalahan disini adalah pada tempat pusat perbelanjaan yang tempat parkirnya dikelola oleh PT. Sky Parking Utama dalam hal pembayaran parkirnya hanya dapat dilakukan melalui pembayaran secara digital yaitu dengan menggunakan dompet elektronik yang dimiliki oleh $\mathrm{OVO}^{27}$ sehingga konsumen tidak memiliki pilihan lain selain menggunakan OVO dalam hal pembayaran.

Menariknya adalah baik OVO dan PT. Sky Parking Utama merupakan perusahaan yang dimiliki oleh Lippo Group. Hampir disetiap tempat perbelanjaan yang dimiliki oleh Lippo akan dikelola oleh PT. Sky Parking Utama dalam hal pengelolaan parkirnya dan kemudian dalam hal pembayaran parkir tersebut akan hanya ada penggunaan OVO sebagai metode pembayaran. Hal tersebut seakan Lippo terlihat menggunakan produk-produk turunannya sendiri sehingga menutupi kesempatan pelaku usaha yang lain untuk masuk ke dalam pasar tersebut sehingga terjadinya ketidak adilan dalam pelaksanaan persaingan usaha yang sehat.

\section{Kegiatan Yang Dilarang (Monopoli)}

Pada dasarnya monopoli merupakan hal yang wajar, bukan merupakan hal yang dilarang oleh hukum. Namun dengan syarat monopoli tersebut di peroleh atas perbuatan yang sah dan tidak melanggar hukum. Tetapi yang dilarang merupakan perbuatan yang dilakukan oleh suatu pelaku usaha apabila dia berada di posisi monopoli dan memanfatkan posisi tersebut untuk menggunakan kekuasaannya terhadap suatu pasar sehingga seakan cenderung menguasai pasar dan calon pesaing yang akan masuk ke dalam pasar tersebut akan terhambat atau adanya barrier to entry. ${ }^{28}$

${ }^{27}$ Ita Farida, Rahmi Zubaedah, Rani Apriani, 'Dinamika Praktik Pembayaran Parkir Menggunakan Satu Dompet Digital' (2020) 1 Singaperbangsa Law Review.[134].

${ }^{28}$ Andi Fahmi Lubis et.al, Op.Cit.[135]. 
Hambatan untuk masuk ke dalam suatu pasar dapat dibagi kedalam dua macam yaitu hambatan teknis (technical barriers to entry) dan hambatan legalitas (legal barriers to entry). Hambatan teknis biasanya di temukan pada perusahaan baru yang ingin masuk bersaing dengan perusahaan yang telah settle, dan perusahaan tersebut terdapat hambatan secara teknis. Hal tersebut terjadi karena perusahaan yang telah ada (existing firm) memiliki kemampuan atau pengetahuan khusus yang tidak dimiliki pesaing lainnya yang mengakibatkan hanya perusahaan tersebut yang dapat melakukan proses produksi secara efisien. ${ }^{29}$

Hambatan legalitas (legal barriers to entry) ini timbul karena adanya peraturan perundang-undangan yang mengatur bahwa untuk beberapa hal yang dirasa vital maka perlu adanya pengaturan harus dikuasai oleh pihak-pihak tertentu (dalam hal ini adalh pemerintah). Selain dari adanya peraturan perundang-undangan secara khusus memperbolehkan untuk memonopoli suatu pasar selanjutnya adalah monopoli tersebut di peroleh atas adanya hak-hak khusus. Hak khusus disini merupakan hak kekayaan intelektual contohnya seperti hak paten atau hak cipta.

Dengan hanya ada terdapat satu pelaku usaha dalam suatu pasar maka hal tersebut belum dapat dikatakan sebagai praktik monopoli, ada beberapa hal yang perlu diperhatikan mengenai unsur apa saja yang dapat dikategorikan sebagai praktik monopoli yaitu:

1) Tidak adanya barang substitusi atau barang pengganti;

2) Adanya hambatan untuk masuk ke dalam suatu pasar bagi pelaku usah lain pada produk yang sama;

3) Pelaku usaha pesaing tersebut merupakan pelaku usaha yang memiliki kemampuan setara dengan pelaku usaha yang telah ada (existing firm) artiya semua pelaku usaha tersebut dapat bersaing tanpa usaha yang susah;

4) Suatu pelaku usaha baik sendiri atau secara berkelompok telah meguasai suatu pasar sebesar lebih dari $50 \%$ atas pangsa pasar dari jenis produk atau jasa tersebut. $^{30}$

Jika unsur-unsur diatas dikaitkan dengan kasus PT. KAI dan LinkAja maka dapat dikatakan sebagai kegiatan monopoli dikarenakan dalam hal pangsa pasar

${ }^{29}$ Susanti, Naskah Akademis Tentang Persaingan Usaha Dan Anti Monopoli, (2005) Puslitbang Hukum dan Peradilan M.A R.I.[75].

${ }^{30}$ Andi Fahmi Lubis et.al, Op.Cit.[138]. 
jasa transportasi kereta api khususnya kereta api lokal masih belum adanya pelaku usaha lain yang terdapat pada pasar tersebut maka dapat dikatakan pangsa pasar tersebut sebesar $100 \%$.

Untuk melihat apakah benar-benar melanggar ketentuan yang ada maka diperlukan adanya pembuktian (rules of reason) untuk memenuhi unsur-unsur yang dapat terjadinya praktik monopoli diantaranya unsur-unsur tersebut adalah pelaku usaha, penguasaan atas produksi barang atau jasa, unsur yang mengakibatkan praktik monopoli yang mengakibatkan pelaku usaha lain tidak dapat masuk ke dalam suatu pasar. Pertama, dalam unsur pelaku usaha sebagaimana di terangkan pada pasal 1 Angka 5 Undang-Undang Nomor 5 Tahun 1999 mengenai definisi pelaku usaha bahwa yang dimaksud pelaku usaha dalam hal ini adalah PT. KAI dan LinkAja yang bekerjasama dalam hal menyediakan jasa perjalanan kereta api dan menyediakan jasa pembayaran melalui dompet digital. Lalu, unsur penguasaan atas produksi baran atau jasa. Yang termasuk ke dalam unsur penguasaan pasar bersangkutan dalam hal ini adalah LinkAja menjadi satu-satunya pilihan dalam metode pembayaran tiket kereta api lokal. Maka dengan hal tersebut setiap konsumen yang ingin membeli tiket kereta api lokal harus menggunakan LinkAja dalam hal pembayaran tiket tersebut karena pelaku usaha seperti OVO, Gopay, ShopeePay, Dana tidak ada dalam pilihan pembayaran tersebut.

Selanjutnya, unsur yang mengakibatkan praktik monopoli, secara teori dapat dikatakan bahwa praktik monopoli merupakan sebuah kegiatan yang dilakukan oleh pelaku usaha atas posisi monopoli tersebut sehingga penyalahgunaan tersebut dapat mengakibatkan praktik monopoli. ${ }^{31}$ Dalam hal ini PT. KAI sebagai satusatunya penyedia jasa perjalanan kereta api di Indonesia khususnya kereta api lokal bekerja sama dengan LinkAja dalam hal melakukan pembayaran tiket kereta api lokal tersebut. Namun KPPU berpendapat melalui siaran persnya Nomor 28/ KPPU-PR/V/2020 tersebut bahwa hanya bekerjasama dengan perusahaan yang dimiliki negara saja (BUMN), kebijakan tersebut bertentangan dengan kesempatan

${ }^{31}$ Peraturan KPPU Nomor 11 Tahun 2011 Tentang Pedoman Pasal 17. 
yang dimiliki oleh penyedia jasa dompet elektronik lainnya seperti OVO, Gopay, ShopeePay, Dana. Dengan adanya uraian atas unsur tersebut dapat dikatakan bahwa secara tidak langsung PT. KAI menghalangi pelaku usaha yang menyediakan jasa dompet elektronik masuk ke dalam pasar tersebut.

\section{Deadweight Loss sebagai Akibat dari Praktik Monopoli}

Di dalam pasar yang berbentuk monopoli adanya keterkaitan antara bentuk pasar tersebut dengan adanya deadweight loss sebagai konsekuensi pada pasar berbentuk monopoli tersebut. Beban bobot hilang atau deadweight loss secara sederhana merupakan sebuah kondisi yang terjadi pada pasar yang berbentuk monopoli ketika harga atas suatu barang atau jasa tersebut ditetapkan hanya oleh adanya satu pelaku usaha tersebut dalam pasar monopoli atau dengan kata lain deadweight loss merupakan sebuah selisih pada surplus konsumen dengan surplus produsen. $^{32}$

Secara umum deadweight loss terjadi akibat adanya keinginan pada pelaku usaha tersebut untuk tetap mempertahankan harga atas barang atau jasa yang di produksi oleh pelaku usaha tersebut untuk di jual dengan harga yang tinggi ${ }^{33}$ karena pelaku usaha tersebut dapat menentukan atas harga semua yang dia mau. Sehingga kegiatan tersebut akan berdampak kepada konsumen, dimana konsumen tidak memiliki pilihan lain selain menerima kebijakan harga yang dikeluarkan oleh pelaku usaha tersebut. Sebenarnya merupakan hal yang wajar untuk mencari keuntungan yang dilakukan oleh suatu pelaku usaha karena memang seperti itu konsekuensi yang ada pada di dunia bisnis, namun adanya kondisi dimana konsumen harus membayar lebih tersebut menjadikan kesejahteraan konsumen berkurang.

Menurut Victor Purba S.H., LLM., Msc. Pengaturan yang ada pada UndangUndang Nomor 5 Tahun 1999 Tentang Larangan Praktek Monopoli dan Persaingan

\footnotetext{
${ }^{32}$ Angelina Ika Rahutami, “Analisis Terkait Persiapan Bioskop Kembali Buka”, Unika News, (Unika News, 2020), https://news.unika.ac.id/2020/09/news-analisis-terkait-persiapan-bioskopkembali-buka/, accessed 3 Januari 2020.

${ }^{33}$ Johnny Ibrahim, Hukum Persaingan Usaha, Filososfi, Teori, dan Implikasi Penerapannya di Indonesia (2006) Banyumedia Publishing.[104].
} 
Usaha Tidak Sehat dirasa belum dapat menjamin rasa keadilan bagi masyarakat atas adanya konsekuensi deadweight loss $^{34}$ yang timbul pada pasar monopoli. Berbeda dengan apa yang ada pada pasar persaingan pasar persaingan sempurna yaitu, harga jual tersebut sama dengan biaya marjinalnya. Sedangkan pada pasar monopoli harga jual tersebut terlalu tinggi tetapi kuantitas produksinya lebih sedikit sehingga pelaku usaha lebih diuntungkan jika dibandingkan dengan konsumennya. ${ }^{35}$ Adanya penurunan surplus konsumen tersebut akan semakin meningkat apabila harga atas barang atau jasa tersebut semakin meningkat kemudian jumlah produksi oleh pelaku usaha tersebut akan semakin turun sehingga adanya transfer kesejahteraan kepada pelaku usaha tersebut. ${ }^{36}$

Dalam kasus ini dimana pada pasar penyedia jasa pembayaran tiket kereta api lokal melalui aplikasi KAI Access hanya terdapat satu pilihan saja dalam hal pilihan pembayarannya yaitu, melalui dompet elektronik yang dimiliki oleh LinkAja. Keadaan tersebut akan mengakibatkan LinkAja sebagai pelaku usaha penyedia jasa dompet elektronik akan mendapatkan keuntungan yang maksimal dikarenakan tidak adanya kompetitor lain dalam pasar tersebut sehingga memiliki power atas kontrol harga dan produksinya yang mengakibatkan konsumen tidak ada pilihan selain membayar tiket kereta api lokal tersebut kecuali menggunakan LinkAja. Namun, akan berbanding terbalik dengan apa yang akan di dapatkan oleh para konsumen yaitu akan menerima penurunan surplus konsumen (consumer loss) yang mengakibatkan penurunan kesejahteraan pada konsumen sedangkan produsen akan menjadi lebih diuntungkan ${ }^{37}$ Keadaan tersebut dapat dilihat melalui gambar dibawah ini:

\footnotetext{
${ }^{34}$ Victor Purba, “Analisa Ekonomi Dari Hukum Persaingan Di Indonesia Adanya Indikasi Pasal 17 UU No. 5 Tahun 1999 Kurang Menjamin Kepastian Hukum Dan Keadilan Dalam Masyarakat" (2001) Jurnal Hukum dan Pembangunan.[113].

${ }^{35}$ ibid.[116].

${ }^{36}$ Gigih Pratomo, "Analisis Welfare Loss Konsumen Sambungan Langsung Jarak Jauh Telepon Tetap Di Indonesi” (2010) 8 Equilibrium.[189-190].

${ }^{37}$ Komisi Pengawas Persaingan Usaha, 'Komisi Pengawas Persaingan Usaha' (2010) 3 Jurnal Persaingan Usaha.[108-109].
} 


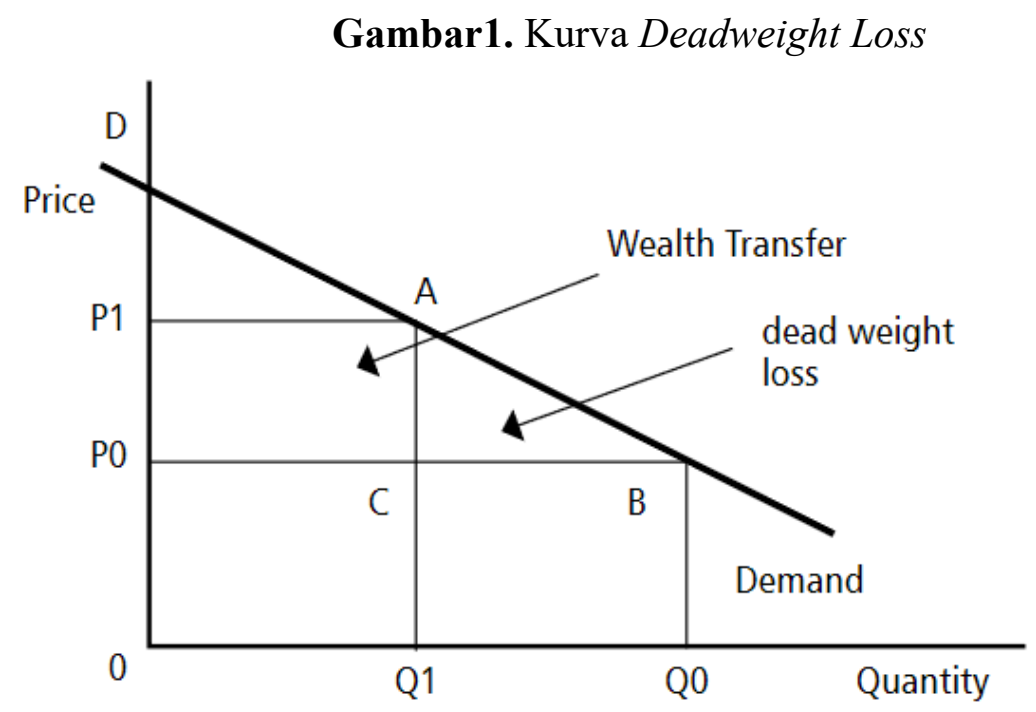

Sumber: KPPU

Melalui gambar tersebut jika kuantitas barang yang diproduksi sebesar Q1 dan dijual dengan harga P1 maka akan terjadi penurunan surplus konsumen yang digambarkan sebesar P1-A-C-P0 yang seharusnya konsumen dapatkan adalah sebesar C-B-Q0-Q1. Kemudian segittiga yang digambarkan oleh A-B-C merupakan yang dinamakan sebagai deadweight loss. Artinya dalam pasar tersebut terdapat ketidakseimbangan dikarenakan barang atau jasa yang dipedagangkan jumlahnya sedikit sedangkan harganya tetap tinggi. Hal tersebut dapat dihindari dengan meningkatkan outputnya yaitu dengan menamasukkan pelaku usaha penyedia jasa pembayaran lainnya sehingga harga yang dikeluarkan akan lebih terjangkau sehingga pasar kembali kompetitif. ${ }^{38}$

\section{Kesimpulan}

Dalam hal pembayaran melalui tiket kereta api lokal hanya dapat dilaksanakan dengan menggunakan aplikasi dompet elektronik LinkAja. Atas adanya kebijakan tersebut dianggap akan menghalangi pelaku usaha lainnya yang terdapat pada pasar bersangkutan yang sama yaitu pada hal ini merupakan pelaku usaha yang juga menyediakan jasa pembayaran secara elektronik seperti Gopay, OVO, Dana,

${ }^{38}$ I Made Sarjana, 'Analisis Pendekatan Ekonomi Dalam Hukum Persaingan Usaha' (2013) 8 (2) Rechtidee.[18]. 
ShopeePay akan merasa dirugikan. Karena perbuatan tersbut dapat menjadi perlakuan yang diskriminatif bagi pelaku usaha lainnya dengan tidak diberi kesempatan yang sama dengan LinkAja untuk bersaing secara sehat dalam hal pembayaran secara elektronik tersebut. Selain pelaku usaha, konsumen juga akan merasa dirugikan dengan hanya adanya satu metode pembayaran pada pemesanan tiket tersbut karena konsumen tidak mempunya pilihan lain untuk menunaikan pembayaran tersebut kecuali mengunduh dan menggunakan aplikasi LinkAja untuk melakukan pembayaran pada aplikasi KAI Access. Kemudian selain kerugian yang dialami oleh pelaku usaha lainnya yang ada pada pasar bersangkutan tersebut, kerugian tersebut dirasakan juga oleh konsumen yang menggunakan aplikasi tersebut dalam hal pembayaran tiket kereta api lokal karena hanya ada satu pilihan saja yaitu pembayaran melalui LinkAja. Para konsumen akan menerima penurunan kesejahteraan (consumer loss) dikarenakan tidak terdapat produsen lain dalam pasar tersebut sehingga konsumen tidak memiliki substitusi, hal ini disebut dengan deadweight loss yaitu penurunan kesejahteraan atas adanya transfer kesejahteraan yang lebih berat kepada produsen sebagai satu satu pelaku usaha.

\section{Daftar Bacaan}

\section{Buku}

John H. Shenefield, Irwin M. Stelzer, The Antitrust Laws: A primer (The AEI Press 2001).

Peter Mahmud Marzuki, Penelitian Hukum (Kencana Prenada Media Group 2011).

R. Shyam Khemani, A Framework For The Design And Implementation of Competition Law and Policy (The World Bank 1999).

Susanti, Naskah Akademis Tentang Persaingan Usaha Dan Anti Monopoli (2005) Puslitbang Hukum dan Peradilan M.A R.I.

\section{Jurnal}

Gigih Pratomo, 'Analisis Welfare Loss Konsumen Sambungan Langsung Jarak Jauh Telepon Tetap Di Indonesi’ (2010) 8 Equilibrium.

I Made Sarjana , 'Analisis Pendekatan Ekonomi Dalam Hukum Persaingan Usaha' 
2338 Enudio Aprilian: Indikasi Praktek Monopoli...

(2013) 8 Rechtidee.

Ita Farida, 'Dinamika Praktik Pembayaran Parkir Menggunakan Satu Dompet Digital' (2020) 1 Singaperbangsa Law Review.

Jefry Tarantang, 'Perkembangan Sistem Pembayaran Pada Era Revolusi Industri 4.0 Di Indonesia' (2019) 4 Jurnal Al-Qaradh.

Komisi Pengawas Persaingan Usaha, 'Jurnal Persaingan Usaha' (2010) 3 Komisi Pengawas Persaingan Usaha.

Muhammad Fahryan Putra, 'Perlindungan Hukum Pengguna Diompet Elektronik Atas Hilangnya Uang Elektronik' (2020) 1 Law Prohuter.

Peter Mahmud Marzuki, 'Penelitian Hukum’ (2001) 16 Yuridika.

Victor Purba, 'Analisa Ekonomi Dari Hukum Persaingan Di Indonesia Adanya Indikasi Pasal 17 UU No. 5 Tahun 1999 Kurang Menjamin Kepastian Hukum Dan Keadilan Dalam Masyarakat' (2001) Jurnal Hukum dan Pembangunan.

\section{Laman}

Antara, "Lima Dompet Digital Paling Banyak DIgunakan Selama Kuartal I", (Media Indonesia 2021) https://mediaindonesia.com/ekonomi/394085/limadompet-digital-paling-banyak-digunakan-selama-kuartal-i, accessed pada 8 Agustus 2021.

Bank Indonesia, "Daftar Penyelenggara Uang Elektronik yang Telah Memperoleh Izin dari Bank Indonesia Per 27 Mei 2020" (Bank Indonesia 2020) https:// www.bi.go.id/id/sistem-pembayaran/informasi-perizinan/uang-elektronik/ penyelenggara-berizin/Contents/Default.aspx accessed 12 September 2020.

Fahmi Ahmad Burhan, “ Riset Awal 2021: Dompet Digital ShopeePay Kalahkan Gopay dan OVO”, (Katadata 2021) https://katadata.co.id/pingitaria/ digital/603 e0bea85b36/riset-awal-2021-dompet-digital-shopeepaykalahkan-gopay-dan-ovo, accessed pada 8 Agustus 2021.

Public Relations KAI, "Seluruh KA Lokal Bisa Dibeli MElalui KAI Access", (KAI 2020) https://kai.id/information/full_news/2269-seluruh-ka-lokal-bisadibeli-melalui-kai-access, accessed pada 13 September 2020.

Siaran Pers KPPU Nomor 28/KPPU-PR/V/2020, “ KPPU Minta PT. KAI Serius Dalam Menciptakan Persaingan Dalam Kerja Sama Bisnisnya”, (KPPU 2020) https://www.kppu.go.id/id/wp-content/uploads/2020/05/Siaran-PersNo.-28_KPPU-PR_V_2020.pdf, accessed pada 16 September 2020. 


\section{Peraturan Perundang-undangan}

Undang-Undang Nomor 5 Tahun 1999 Tentang Larangan Praktek Monopoli dan Persaingan Usaha Tidak Sehat.

Peraturan Bank Indonesia Nomor 20/6/PBI/2018 Tentang Uang Elektronik.

Peraturan Bank Indonesia Nomor 18/40/PBI/2016 Tentang Penyelenggaraan Pemrosesan Transaksi Pembayaran.

Peraturan KPPU No. 3 Tahun 2009 Tentang Pedoman Penerapan Pasal 1 Angka 10 Tentang Pasar Bersangkutan Berdasarkan Undang-Undang Nomor 5 Tahun 1999 Tentang Larangan Praktek Monopoli dan Persaingan Usaha Tidak Sehat.

Peraturan KPPU Nomor 11 Tahun 2011 Tentang Pedoman Pasal 17. 
Enudio Aprilian: Indikasi Praktek Monopoli...

--halaman ini sengaja dibiarkan kosong-- 